\title{
Estrogen response element enhances adenovirus-mediated transfer of the p53 gene according to codon 72 polymorphisms and cellular estrogen receptor expression
}

\author{
Koji Kajitani ${ }^{1}$, Ken-ichi Honda ${ }^{2,3^{*}}$, Hiroyuki Terada ${ }^{3}$, Minoru Ayata ${ }^{4}$, Takeshi Fukuda ${ }^{3}$, Hiroyuki Yoshida ${ }^{3}$, Tomoyo Yasui ${ }^{3}$, \\ Toshiyuki Sumi ${ }^{3}$ and Osamu Ishiko ${ }^{3}$ \\ Correspondence: kenhonda@med.osaka-cu.ac.jp \\ 'Department of Obstetrics and Gynecology, Izumiotsu Municipal Hospital, 16-1 Gejocho, Izumiotsu, Osaka, Japan. \\ 2Department of Gynecology, Izumi Municipal Hospital, 4-10-10 Fuchucho, Izumi, Osaka, Japan. \\ ${ }^{3}$ Department of Obstetrics and Gynecology; \\ ${ }^{4}$ Department of Virology, Osaka City University Graduate School of Medicine, 1-4-3 Asahimachi, Abeno-ku, Osaka, Japan.
}

\begin{abstract}
Background: Relations between response systems for estrogen receptors and p53 with codon 72 polymorphism in cancer cell lines are suggested through experiments for adenovirus-mediated p53 gene delivery.

Methods: Recombinant adenoviruses containing an upstream estrogen response element (ERE)-linked p53 gene (bases 166-1143 from the start codon) were prepared for the infection of HHUA endometrial cancer cells, KLE endometrial cancer cells, or SW48 colon cancer cells, and transduction of p53 gene was measured by real time PCR.

Results: The transduction of the ERE-linked p53 gene with a proline variant at codon 72 in HHUA cells or in SW48 cells, which express estrogen receptor $\beta$, was over ten-fold greater than the transduction of the unlinked p53 gene. The transduction of the ERE-linked p53 gene with an arginine variant at codon 72 in KLE cells, which do not express estrogen receptor, was over ten-fold greater than the transduction of the unlinked p53 gene.

Conclusion: ERE-linked p53 gene may be efficiently transducted to cancer cells according to codon 72 polymorphisms and cellular estrogen receptor expression.
\end{abstract}

Keywords: Adenovirus vector, codon 72 polymorphism, estrogen receptor, estrogen response element, p53

\section{Background}

The proline-rich region (residues 64-93) of the p53 tumor suppressor protein regulates apoptosis and inhibits MDM2mediated p53 degradation [1,2]. Polymorphisms in codon 72 of p53 (proline or arginine) are represented by the nucleotide sequences, CCC or CGC, at nucleotides 214-216. Storey et al. suggested that women with the homozygous CGC variant were seven times more susceptible to cervical cancer in comparison to CCC homozygotes [3]. Reports that cancer patients with the arginine variant at codon 72 of the $\mathrm{p} 53$ gene have a better prognosis are controversial $[4,5]$, and so other factors may affect p53 gene function. Menendez et al. showed that p53-mediated transcription is increased by the estrogen receptor acting as a transcription factor in cultured cells transfected with a recombinant gene containing an estrogen responsive element (ERE) and a p53 responsive element [6]. ERE is a DNA sequence, -GGTCAnnnTGACC-, to which estrogen receptors (ERs) bind in order to activate the transcription of target genes [7]. We expected that the relation between response systems for estrogen receptors and $\mathrm{p} 53$ could be applied to promote adenovirus-mediated p53 gene transfer in ERexpressing cells and there would be differences in cellular response according to codon 72 polymorphisms of p53. In this study, upstream ERE-linked p53 genes were inserted into adenovirus vectors and used to infect cancer cell lines, supposing selective transduction of ERE-linked p53 gene to the cells expressing ERs. The effects of ERE on the cellular reaction against the recombinant adenoviruses seemed to be quite different between the proline variant and arginine variant p53 genes, and also different between in ER-expressing cells and in ER-not expressing cells.

\section{Materials and methods \\ Plasmids}

Human cDNAs were amplified by RT-PCR from total RNA purified from chorionic tissue obtained at 11 weeks of gestation with informed consent [8]. The p53 gene (bases 166- 1143 from the start codon, including the last non-coding 21 nucleotides) was amplified with the forward primer, GAAGACCCAGGTCCAGAT, and the reverse primer, TTTATGGCGGGAGGT. To

C 2012 Honda et al; licensee Herbert Publications Ltd. This is an open access article distributed under the terms of Creative Commons Attribution License (http://creativecommons.org/licenses/by/3.0),This permits unrestricted use, distribution, and reproduction in any medium, provided the original work is properly cited. 
incorporate an EcoR1 site together with the ERE and the start codon at the 5 ' terminal, the forward primer, GAATTCGGTCATAGTGACCATATGGAAGACCCAGGTCCAGAT, and the reverse primer, AGTGTGATGGATATCTGCAGAATTCTTTATGGCGGGAGGT, were used to amplify the ERE-linked p53 gene [8]. To incorporate an EcoR1 site together with the start codon but without the ERE at the 5 ' terminal, the forward primer, AGGAATTCATGGAAGACCCAGGTCCAGAT, and the reverse primer, CAGAATTCTTTATGGCGGGAGGT, were used to amplify an ERE-unlinked $\mathrm{p} 53$ gene. These $P C R$ products were gel purified, ligated into the PGEM-T Easy vector (Promega, Madison, WI, USA), and transfected into competent $E$. coli DH5a cells (Competent High, Toyobo, Osaka, Japan). The amplified plasmids were digested with EcoRI and ligated into pIRES-hrGFP-1 (Agilent Technologies). For the polymorphic variants at codon 72 of $\mathrm{p} 53$, the arginine variant (CGC) CDNA isolated from chorionic tissue was changed to the proline variant (CCC) by using the QuikChange II Site-Directed Mutagenesis Kit (Agilent Technologies) with the primers, GCCAGAGGCTGCTCCCCC and CGTGCAAGTCACAGACTT.

\section{Recombinant adenoviruses}

The ERE-linked or ERE-unlinked p53 genes and their arginine variants (EREp53R or p53R) or proline variants (EREp53P or p53P) at codon 72 were excised by digestion with EcoRV and Xhol, and inserted into the pShuttle-IREShrGFP-1 shuttle vector (Agilent Technologies) (Figure 1). After linearization by Pmel digestion and gel purification without dephosphorylation, the p53 gene constructs were electroporated into BJ5183-AD-1 cells pre-transformed with E1-deficient adenovirus vector. The recombinant adenoviruses were amplified in XL-10 ultracompetent cells, digested with Pacl and used to infect AD-293 cells. The adenovirus inserted with arginine variant or proline variant was indicated as Ad-p53R or Ad-p53P, and the corresponding ERE-linked adenovirus was indicated as Ad-EREp53R or Ad-EREp53P.

To prepare viral stocks, AD-293 cells that were fully GFP-positive at 3 days after infection were collected, and the adenoviruses were extracted from the supernatants by centrifugation of the cells after four rounds of rapid freezing in methanol cooled with dry ice and thawing in a $37^{\circ} \mathrm{C}$ water bath. The adenoviruses were purified using a Virabind Adenovirus Miniprep kit (Cell Biolabs Inc., San Diego, CA, USA) and stored in $10 \%$ glycerol at $-80^{\circ} \mathrm{C}$

\section{SDS gel electrophoresis of purified recombinant adenoviruses \\ Proteins in the purified adenovirus solutions were separated on any kD-precast TGX polyacrylamide gels (Bio-Rad, Hercules, CA, USA) and stained with Coomassie brilliant blue $R$. The hexon protein was identified by western blotting with an anti-hexon mouse antibody and anti-mouse lgG in the adenovirus titration kit (Agilent Technologies).}

Quantification of shuttle vectors or recombinant adenoviruses containing the $\mathbf{p} 53$ gene by real time PCR To isolate adenovirus DNA (the isolation step can be omitted for real time PCRs), viruses in solution or in cultured cells were lysed with $0.6 \%$ SDS containing 10 mM EDTA, followed by protein precipitation with 0.3 volumes of $5 \mathrm{M} \mathrm{NaCl}$, and the DNA was precipitated with 3 volumes of cold ethanol and dissolved in water. For TaqMan real-time PCR, the forward primer, GAATTGCTATTATTTGTCGTCATCA, the reverse primer, AGGTAGACTGACCCTTTTTGGACTT, and the probe (CCTTGTAGTCCTCGAGTTA conjugated with FAM (6-carboxy fluorescein) on the $5^{\prime}$ end and with minor groove binder (MGB) on the $3^{\prime}$ end; Applied Biosystems, CA, USA) corresponding to the junction region between the $3^{\prime}$ end of the p53 insert and the Xhol site of the shuttle vector, were used to quantify the copy number of adenovirus containing p53 constructs [9]. The real time PCRs were performed to analyze the absolute copy numbers of transducted recombinant adenovirus in the cells in each well on a 7500 Fast real time PCR System (Applied Biosystems).

\section{Cell culture}

The HHUA human endometrial cancer cell line, which expresses ER $\beta$ [10], was supplied by Riken Laboratories (Wako, Saitama, Japan). The SW48 human colon cancer cell line [11] and the KLE human endometrial cancer cell line [12] were supplied by DS Pharma Biomedical Co. (Osaka, Japan). The SW48 cells were cultured in minimal essential medium supplemented with $10 \%$ FBS. In preliminary experiments, the HHUA cells and SW48 cells were found to express the arginine variant at codon 72 p53 gene without any mutations in bases 166-1203 from the start codon. HHUA cells were found to express ER $\beta$ but not ERa [13]. SW48 cells were found to express ERs by real time PCR (data not shown). KLE cells, which have a mutation at codon 213 of the p53 gene [12], were found not to express ERs.

The HHUA cells and KLE cells were cultured in F-12/ minimal essential medium (1:1) (Invitrogen, Carlsbad, CA, USA) supplemented with $15 \%$ charcoal-stripped FBS (HyClone Laboratories, Logan, UT, USA) at $37^{\circ} \mathrm{C}$ in a humidified incubator containing $5 \% \mathrm{CO}_{2}$. The concentration of estradiol in the medium supplemented with FBS was about $10^{-10} \mathrm{M}$.

For viral infection, cultured cells were dispersed with $0.25 \%$ trypsin/1 mM EDTA, washed, and inoculated into $12-$ well (24-mm diameter) tissue culture plates (BM Equipment Co. Tokyo, Japan). For infection with the same copy number of adenovirus DNA for each insert, ; the volume of adenovirus stock was adjusted according to the quantification data by TaqMan real-time PCR assay, corresponding to a multiplicity of infection of about 10.

\section{Titration of recombinant adenoviruses}

AD293 cells in 24-well tissue culture plates (BD Biosciences, San Jose, CA, USA) were infected with $50 \mu$ l of 10 -fold 
serially-diluted recombinant adenovirus. The cells were fixed with methanol and the adenoviral hexon protein was stained with an anti-hexon mouse antibody followed by horseradish peroxidase-conjugated goat secondary antibody, and bound antibodies were detected by reaction with diaminobenzidine (AdEasy Viral Titer kit, Agilent Technologies). The number of hexon-positive cells was counted under a microscope and the number of infectious units (IFU) per ml was calculated.

\section{RT-PCR assay}

Total RNA was extracted from the HHUA cells at $72 \mathrm{~h}$ after adenovirus infection using an RNeasy Mini kit (Qiagen Sciences, Valencia, CA, USA). High Capacity cDNA Reverse Transcription kit (Applied Biosystems) were used to synthesize cDNA from the RNA. The relative expression levels of target mRNAs, compared to the level of $18 \mathrm{~S}$ ribosomal RNA, were analyzed by real time PCR with the corresponding TaqMan MGB probes and primers (Hs00153349_m1 for p53, Hs00154661_m1 for coxsackievirus and adenovirus receptor (CAR), Hs00914223_m1 for p300 using the multiplex threshold method on a 7500 Fast Real Time PCR System (Applied Biosystems).

Treatment of HHUA cells with estradiol or radiation and flow cytometry

We studied the effects of $10^{-9} \mathrm{M} \beta$-estradiol treatment or $10 \mathrm{~Gy}$ radiation at $24 \mathrm{~h}$ after adenovirus infection on the expression of $p 53$ and p300, which accelerates p53 turnover by polyubiquitination, and on the annexin $\mathrm{V}$ binding, as an indicator of early phase apoptosis, and propidium iodide (PI) staining, as an indicator of late phase apoptosis in HHUA cells.

For the estradiol-treated group, the HHUA cells were incubated in medium containing $10^{-9} \mathrm{M} \beta$-estradiol from the start of adenovirus infection. $\beta$-estradiol (Wako Pure Chemicals) was first dissolved at $10^{-5} \mathrm{M}$ in ethanol, and then diluted 1:10,000 in culture medium. For the untreated group and the radiation group, $0.01 \%$ ethanol was included in the culture medium.

For the radiation group, the HHUA cells were exposed to $10 \mathrm{~Gy} \mathrm{X}$-ray irradiation at $150 \mathrm{kV}$ on the $\mathrm{X}$-ray apparatus (MBR-1320R, Hitachi, Tokyo, Japan) $24 \mathrm{~h}$ after adenovirus infection.

Forty-eight hours after infection with recombinant adenoviruses, the HHUA cells were dispersed with $0.25 \%$ trypsin $/ 1 \mathrm{mM}$ EDTA, washed with PBS and stored at $-80^{\circ} \mathrm{C}$ for RT-PCR assay, or suspended in $50 \mathrm{mM}$ Tris- $\mathrm{HCl}(\mathrm{pH} 8.0), 80$ $\mathrm{mM} \mathrm{NaCl}, 0.2 \% \mathrm{BSA}, 2.5 \mathrm{mM} \mathrm{CaCl}_{2}$, and then incubated with phycoerythrin-conjugated annexin V (BD Biosciences). The cells were analyzed by flow cytometry, and cells expressing GFP were detected at 515-545 nm, and cells binding to annexin $V$ were detected at 564-606 nm, and the doublepositive rates in GFP positive cells were counted.

Seventy two hours after infection with recombinant adenoviruses, the HHUA cells were dispersed with $0.25 \%$ trypsin $/ 1 \mathrm{mM}$ EDTA, washed with PBS and stored at $-80^{\circ} \mathrm{C}$ for RT-PCR assay, or stained with PI (BD Biosciences) (detected at $>650 \mathrm{~nm}$ ), and the double-positive rates in GFP positive cells were counted.

\section{Statistical analysis}

Copy numbers of recombinant adenoviruses in the cells, relative mRNA expression levels, annexin $\mathrm{V}$ binding rates, and propidium iodide staining rates were analyzed by nonparametric methods using PASW Statistics 18 Software (SPSS, Chicago, IL, USA), and results with $\mathrm{p}<0.05$ were judged as significant.

\section{Results}

SDS gel electrophoresis of purified recombinant adenoviruses

By SDS gel electrophoresis, the protein composition of each recombinant adenovirus constructed from corresponding p53 gene-inserted shuttle vector shown in Figure 1 was identical, including the hexon confirmed by Western blotting (Figure 2).

Quantification of shuttle vectors and recombinant adenoviruses containing p53 gene inserts by realtime PCR

The quantification curves for Shuttle-p53R, Shuttle-p53P, Shuttle-EREp53R and Shuttle-EREp53P were identical (Figure 3). The copy numbers of adenoviruses containing p 53 gene inserts in the isolated virus solution or in the cell lysate were calculated from the corresponding amplification cycle numbers on-the quantification curve.

Analysis of GFP positive cells infected with recombinant adenoviruses by fluorescence microscopy A greater number of HHUA cells was infected with AdEREp53P (Figure 4D) compared to Ad-p53R, Ad-p53P and Ad-EREp53R (Figure 4A, 4B, 4C). However, a greater number of KLE cells was infected with Ad-EREp53R (Figure 4G) compared to Ad-p53R, Ad-p53P or Ad-EREp53R (Figure $4 E, 4 F, 4 H)$.

Titration of recombinant adenoviruses in AD293 cells In accordance with the manufacturer's protocol, a significantly higher titer of Ad-EREp53P compared to Ad-p53R, Ad-p53P and Ad-EREp53R was noted (Figure 5). The difference was considered to depend on the greater transduction rates of Ad-EREp53P than other recombinant adenovirus into AD293 cells, which were found by real time PCR to express ERs (data not shown).

High transduction for Ad-EREp53P in HHUA cells or SW48 cells, and high transduction for Ad-EREp53R in KLE cells

The transduction in HHUA cells were over ten-fold higher 
Kajitani et al. Journal of Cancer Therapeutics \& Research 2012, http://www.hoajonline.com/journals/pdf/2049-7962-1-31.pdf
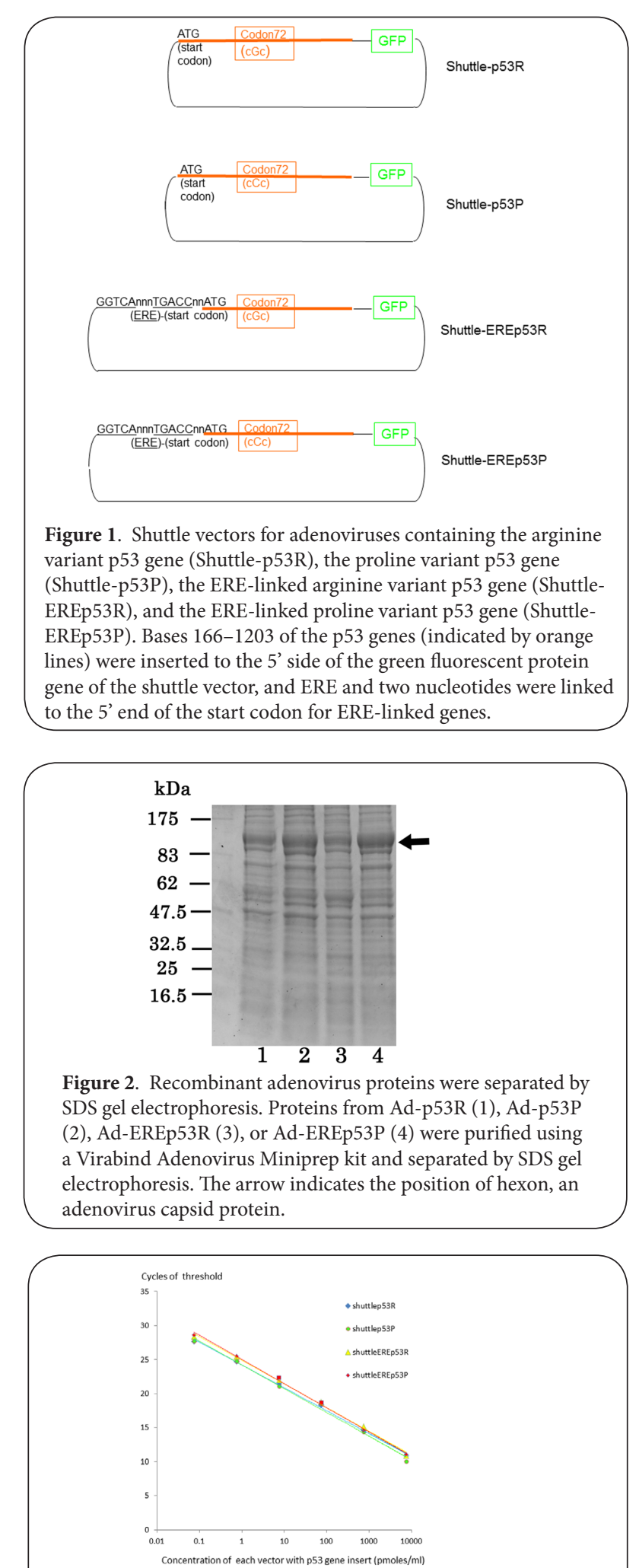

Figure 3. Quantification of shuttle vectors containing p 53 genes by real-time PCR. Shuttle-pIRES-hrGFP containing p53R (blue), p53P (green), EREp53R (yellow), and EREp53P (red) were quantifed with the TaqMan probe and primers overlapping the 3' end of the p53 gene and the 5' end of the ligation site in the shuttle vector.
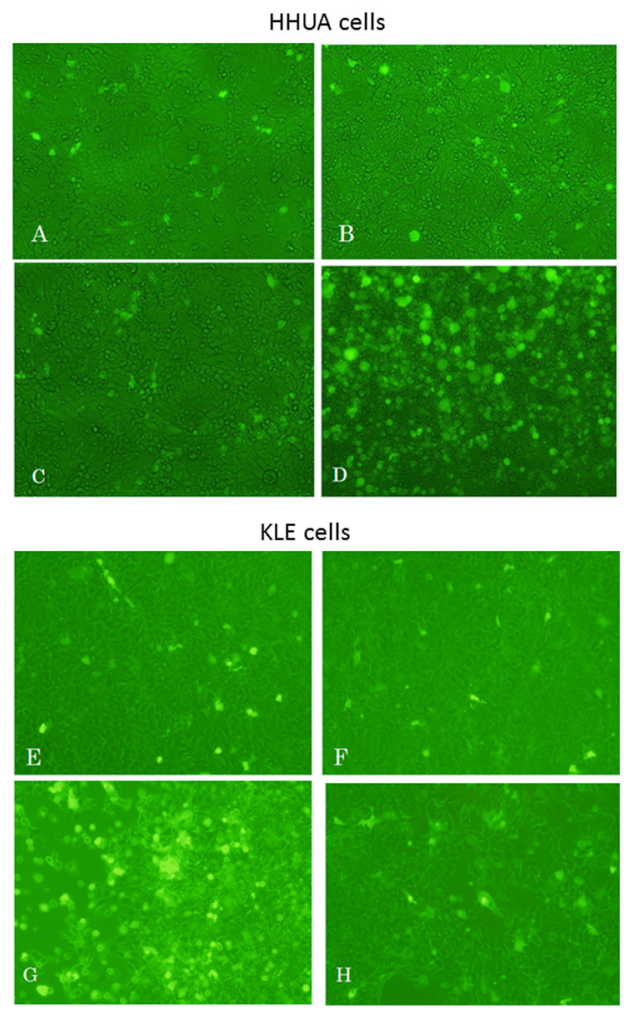

Figure 4. GFP fluorescence in HHUA cells $48 \mathrm{~h}$ after infection with Ad-p53R (A), Ad-p53P (B), Ad-EREp53R (C) or Ad-EREp53P (D), and in KLE cell $48 \mathrm{~h}$ after infection with Ad-p53R (E), Ad-p53P (F), Ad-EREp53R (G) or AdEREp53P (H). The cells were photographed with a 530/40 $\mathrm{nm}$ filter on an inverted fluorescence microscope (IX71; Olympus, Tokyo, Japan).

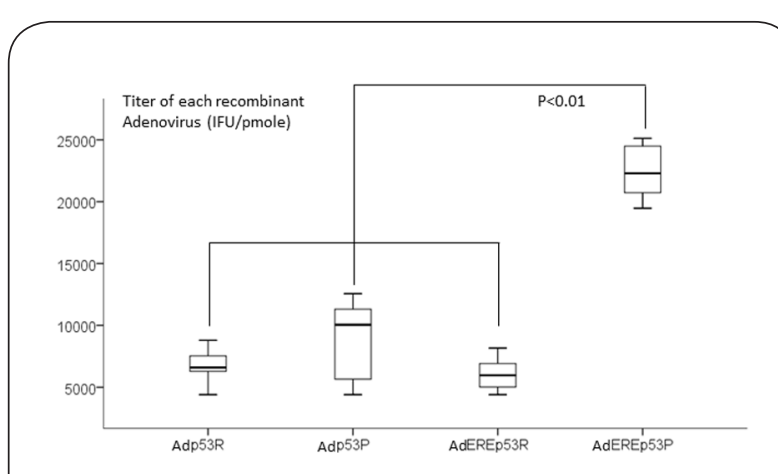

Figure 5. Titer of each recombinant adenovirus by AdEasy Viral Titer kit. Titer was determined by counting the number of AD293 cells positive for hexon protein at $48 \mathrm{~h}$ after infection. 

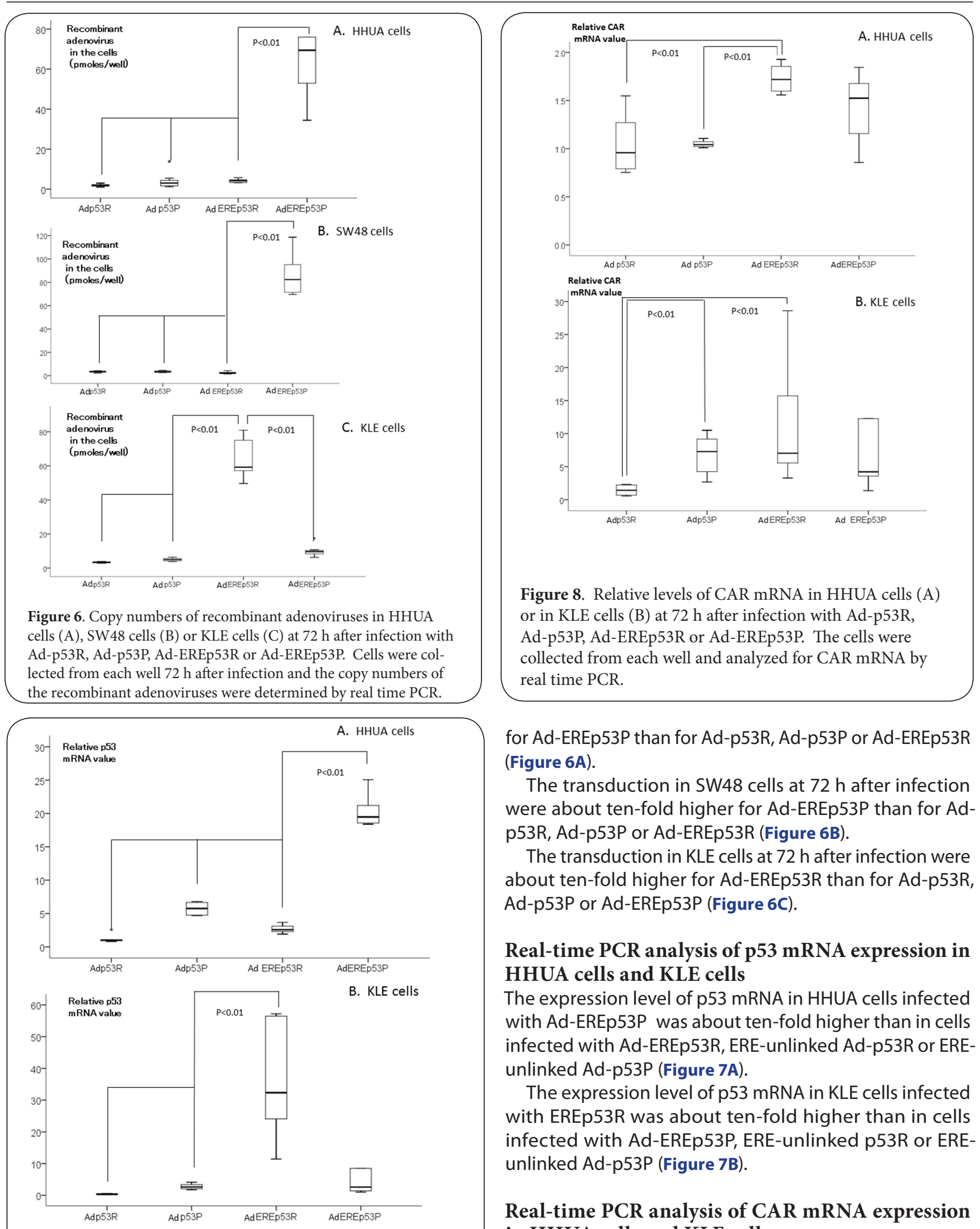

Figure 7. Relative levels of p53 mRNA in HHUA cells (A) or in KLE cells (B) at $72 \mathrm{~h}$ after infection with Ad-p53R, Ad-p53P, Ad-EREp53R or Ad-EREp53P. The cells were collected from each well and analyzed for p53 mRNA by real time PCR.

for Ad-EREp53P than for Ad-p53R, Ad-p53P or Ad-EREp53R (Figure 6A).

The transduction in SW48 cells at $72 \mathrm{~h}$ after infection were about ten-fold higher for Ad-EREp53P than for Adp53R, Ad-p53P or Ad-EREp53R (Figure 6B).

The transduction in KLE cells at $72 \mathrm{~h}$ after infection were about ten-fold higher for Ad-EREp53R than for Ad-p53R, Ad-p53P or Ad-EREp53P (Figure 6C).

\section{Real-time PCR analysis of p53 mRNA expression in HHUA cells and KLE cells}

The expression level of p53 mRNA in HHUA cells infected with Ad-EREp53P was about ten-fold higher than in cells infected with Ad-EREp53R, ERE-unlinked Ad-p53R or EREunlinked Ad-p53P (Figure 7A).

The expression level of $\mathrm{p} 53$ mRNA in KLE cells infected with EREp53R was about ten-fold higher than in cells infected with Ad-EREp53P, ERE-unlinked p53R or EREunlinked Ad-p53P (Figure 7B).

\section{Real-time PCR analysis of CAR mRNA expression} in HHUA cells and KLE cells

The expression level of CAR mRNA in HHUA cells infected with Ad-EREp53R was significantly higher than in cells infected with ERE-unlinked Ad-p53R or ERE-unlinked Ad- 


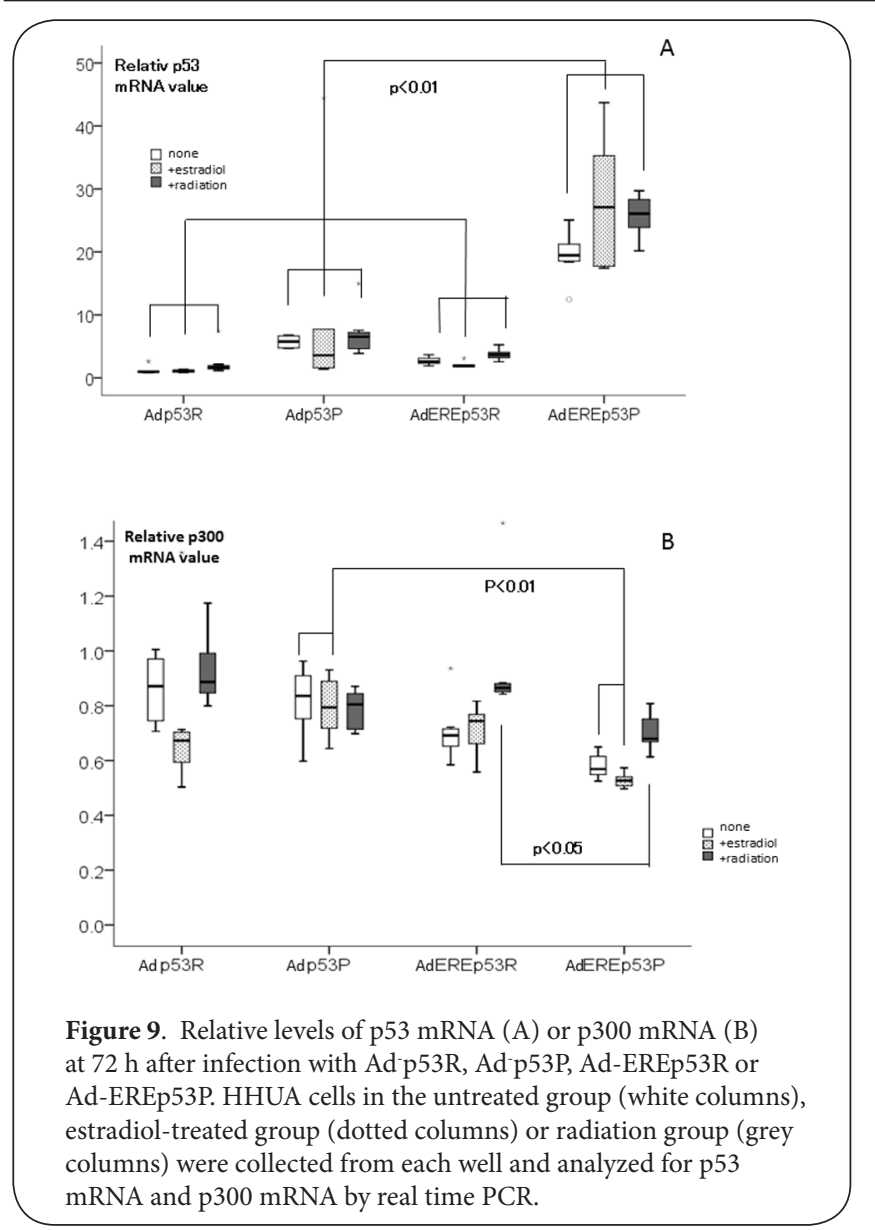

p53P (Figure 8A).

The expression levels of CAR mRNA in KLE cells infected with Ad-EREp53R or ERE-unlinked Ad-p53P were significantly higher than in cells infected with ERE-unlinked Ad-p53R (Figure 8B).

Real-time PCR analysis of p53 mRNA and p300 mRNA expression in HHUA cells treated with $10^{-9}$ $M$ estradiol or $10 \mathrm{~Gy}$ radiation

We found no differences in the levels of p53 mRNA expression between the untreated group, the estradioltreated group and the radiation group (Figure 9A).

In the untreated group and estradiol-treated group, the p300 mRNA levels in HHUA cells infected with Ad-EREp53P were lower than in cells infected with the ERE-unlinked p53P gene (Figure 9B). In cells in the radiation group, the p300 mRNA expression levels were lower in cells infected with Ad-EREp53P than in cells infected with Ad-EREp53R (Figure 9B).

Flow cytometric analysis of annexin $\mathrm{V}$ binding and propidium iodide staining in HHUA cells treated with or without estradiol or $10 \mathrm{~Gy}$ radiation

We also studied the effects of $10^{-9} \mathrm{M} \beta$-estradiol or 10
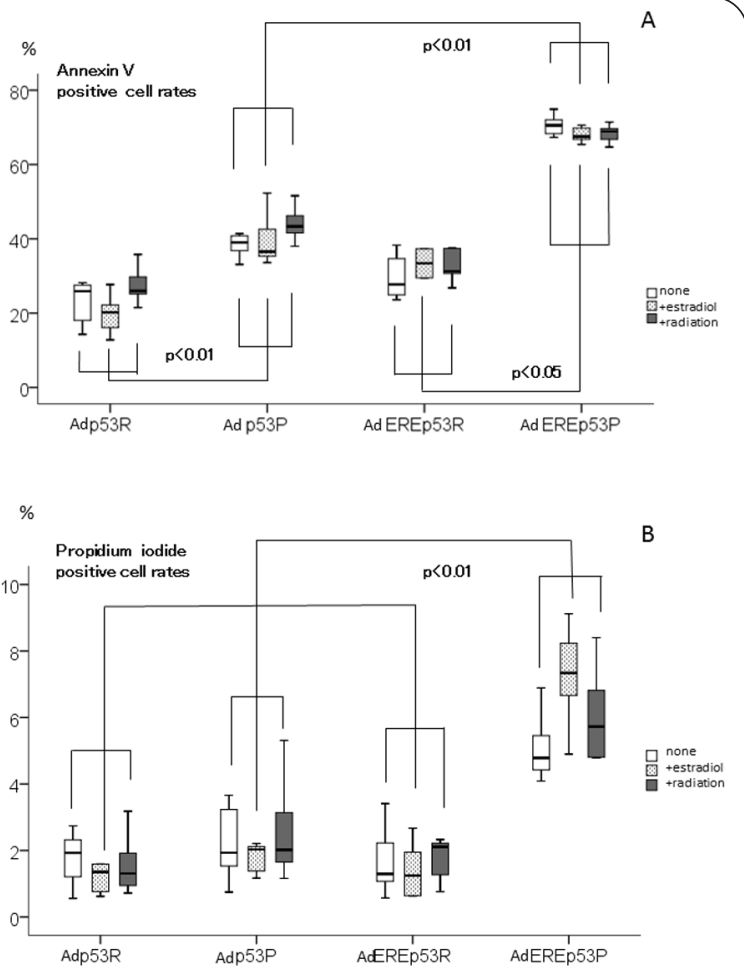

Figure 10. Annexin V binding cell rates at $48 \mathrm{~h}(\mathrm{~A})$ or propidium iodide staining cell rates at $72 \mathrm{~h}$ (B) after infection with Ad-p53R, Ad p53P, Ad-EREp53R or Ad-EREp53P. HHUA cells in the untreated group (white columns), estradiol-treated group (dotted columns) or radiation group (grey columns) were collected from each well and determined by flow cytometry.

Gy radiation at $24 \mathrm{~h}$ after adenovirus infection on early phase apoptosis, as demonstrated by annexin $\mathrm{V}$ binding, and late phase apoptosis, as demonstrated by PI staining, in HHUA cells.

At $48 \mathrm{~h}$ after infection of HHUA cells with recombinant adenoviruses, the annexin $\mathrm{V}$ binding rate was higher in cells infected with Ad-p53P than in cells infected with Ad-p53R. Also, the annexin $\mathrm{V}$ binding rate was higher in cells infected with Ad-EREp53P than in cells infected with Ad-p53P or with Ad-EREp53R (Figure 10A). No differences in annexin $\mathrm{V}$ binding in HHUA cells were found between the untreated group, the estradiol-treated group and the radiation group.

At $72 \mathrm{~h}$ after infection of HHUA cells with recombinant adenoviruses, the PI staining rate was higher in cells infected with Ad-EREp53P than in cells infected with Ad-EREp53R, Ad-p53R or Ad-p53P (Figure 10B). No differences in the PI staining of HHUA cells were found between the untreated group, the estradiol-treated group and the radiation group.

\section{Discussion}

It has been suggested that crosstalk exists between the estrogen receptor and the transcriptional network via the p53 gene. It has also been shown that p53 can mediate 
the transactivation of responsive elements by synergizing with ER at locations in the DNA sequence near to the ERE and p53 responsive element [14]. In contrast, ERE can be used as a promoter to induce the transcriptional activation of adenovirus genes to obtain restricted replication by complementation of the E1a protein [15]. In our study, the transduction efficiencies of adenovirus gene containing an upstream ERE linked-exogenous p53 gene and the expression levels of $\mathrm{p} 53$ mRNA in cultured cells were greater than those not linked to ERE.

In our previous study [8], HHUA cells transfected with a plasmid vector containing an ERE-linked p53 gene with the proline variant polymorphism at codon 72 showed increased p21 expression. Although infection of recombinant adenovirus containing ERE-linked p53 genes didn't make no difference in p21mRNA induction (data not shown), the transduction rates of recombinant adenoviruses containing the ERE-linked proline variant p53 gene were over ten-fold greater than the unlinked p53 genes in ERexpressing HHUA cells derived from endometrial cancer and also in ER-expressing SW48 cells derived from colon cancer. Surprisingly, the transduction rates of recombinant adenoviruses containing the ERE-linked arginine variant $\mathrm{p} 53$ gene were over 10 -fold greater than the transduction rates of recombinant adenoviruses containing the unlinked p53 gene in KLE cells, which are derived from endometrial cancer but do not express ER. Unknown intracellular changes may occur after transduction with these constructs.

CAR is an important entry site factor, and the expression level of CAR was higher after infection with EREp53R in both HHUA cells and KLE cells. We hypothesized that the function of CAR in promoting adenovirus entry was negated in HHUA cells in which stronger factors promote the transduction of the proline variant p53 gene. Cyclic AMP dependent protein kinase (PKA) is known to play a role in the nuclear transport of infected virus genes [16]. PKA mRNA expression was detected at higher levels in HHUA cells and in SW48 cells than in KLE cells by real time PCR (data not shown). ER is activated by CAMP even in the absence of exogenous hormone, and ERE is necessary for CAMP dependent gene expression via ER $\beta$ [17].

For the role of codon 72 polymorphisms in the p53 gene, some functional differences between the proline and arginine variants of $p 53$ have been suggested [18]. The apoptotic potential of the arginine variant has been shown to be related to its greater localization in the mitochondria [18]. The higher efficiency of mitochondria-targeted p53 gene delivery in xenografted human tumor models compared to nuclear delivery suggests the importance of mitochondrial transfer of p53 [19].

The inclusion of $10^{-9} \mathrm{M} \beta$-estradiol in the culture medium made no obvious difference to the responses of HHUA cells to recombinant adenovirus infection. The concentration $\left(10^{-9} \mathrm{M}\right)$ of estradiol in the culture medium of cells in the estradiol group was 10-fold greater than the basal concentration of estradiol $\left(10^{-10} \mathrm{M}\right)$ in the medium of cells in the untreated group. The p300 mRNA levels in HHUA cells infected with Ad-EREp53P were lower than in cells infected with the ERE-unlinked p53P gene. Because there was no differences between the untreated group and the estradiol group, the increased response of HHUA cells to the recombinant adenovirus containing an ERE-linked proline variant p53 gene is considered to be hormone-independent.

There was also no difference in the responses of HHUA cells to recombinant adenoviruses between untreated group and the $10 \mathrm{~Gy}$ irradiated group. The p53 gene product promotes cell sensitivity to low energy radiation $[20,21]$, and it has been reported that adenoviral-mediated delivery of the p53 gene in vitro and in vivo increased cancer cell sensitivity towards radiation [22]. Radiation caused no additional effects on the p53 mRNA level in HHUA cells in our study, and the expression of p300 mRNA was kept when the cells were infected either with Ad-p53P or with Ad-EREp53R. However, suppression of p300 mRNA expression was observed following infection with AdEREp53P, suggesting that the codon 72 polymorphism rather than the upstream ERE is more important for the effect of p53 on p300 expression. As cyclic AMP response element binding protein (CREB) and p300 contribute to the ability of estrogen receptor to trans-activate target genes [23], and p300 play roles with CREB-binding protein to induce apoptosis by ionizing radiation [24]. After transduction of the proline variant p53 gene in HHUA cells, the low expression of p300 may attenuate p53 degradation because p300 exhibits intrinsic ubiquitin ligase activity $[25,26]$.

As transcriptional effects of PKA are mediated through CREB, lower p300 mRNA level in HHUA cells may be related to the interaction with CREB-binding proteins. Neither PKA mRNA nor p300 mRNA were detected in ER-negative KLE cells (data not shown). We are considering that future study using arginine-variant p53 gene which induces greater p53 mRNA in ER-neagtive KLE cells by other indicators may help to prepare an efficient ERE-linked p53 gene therapy for ER-negative neoplasia.

\section{Conclusions}

An ERE-linked p53 gene with codon 72 polymorphism of proline variant or arginine variant are over 10 -fold greater transducted than unlinked one in the ER-expressing cells or ER-not_expressing cells, respectively. These relations may be applied to the efficient adenovirus-mediated transfer of p53 gene.

\section{Competing interests}

The Authors' declare that they have no competing interests.

\section{Authors' contributions}

$\mathrm{KK}, \mathrm{KH}, \mathrm{HT}, \mathrm{MA}, \mathrm{TF}, \mathrm{HY}, \mathrm{TY}, \mathrm{TS}$, OI were all involved in designing the study. $\mathrm{KK}$ and $\mathrm{KH}$ wrote the first draft 
of the manuscript. All authors reviewed the data and were involved in the final analysis and conclusions.

\section{Acknowledgements}

We thank Masatsugu Kimura, and Hiroo Nakagawa, at the Radioisotope Centre, for their technical assistance during the irradiation of cultured cells, Yukimi Kira, Yoriko Yabunaka and Mika Egami at the Central Laboratory of Osaka City University Graduate School of Medicine for their technical supports during the biomolecular analyses.

Publication history

Received: 18-Sep-2012 Revised: 16-Oct-2012

Accepted: 25-Oct-2012 Published: 09-Nov-2012

\section{References}

1. Baptiste N, Friedlander $P$, Chen $X$, Prives C: The proline-rich domain of p53 is required for cooperation with anti-neoplastic agents to promote apoptosis of tumor cells. Oncogene 2002, 21:9-21. | Article | PubMed

2. Liu G, Xia T, Chen X: The activation domains, the proline-rich domain, and the C-terminal basic domain in p53 are necessary for acetylation of histones on the proximal p21 promoter and interaction with p300/ CREB-binding protein. J Biol Chem 2003, 278:17557-17565. | Article I PubMed

3. Storey A, Thomas M, Kalita A, Harwood C, Gardiol D, Mantovani F, Breuer J, Leigh IM, Matlashewski G, Banks L: Role of a p53 polymorphism in the development of human papillomavirus-associated cancer. Nature 1998, 393:229-234. I Article | PubMed

4. Toyama T, Zhang Z, Nishio M, Hamaguchi M, Kondo N, Iwase H, Iwata H, Takahashi S, Yamashita H, Fujii Y: Association of TP53 codon 72 polymorphism and the outcome of adjuvant therapy in breast cancer patients. Breast Cancer Res 2007, 9:R34. | Article | PubMed Abstract I PubMed Full Text

5. Han JY, Lee GK, Jang DH, Lee SY, Lee JS: Association of p53 codon 72 polymorphism and MDM2 SNP309 with clinical outcome of advanced nonsmall cell lung cancer. Cancer 2008, 113:799-807. | Article | PubMed

6. Menendez D, Inga A, Resnick MA: Potentiating the p53 network. Discov Med 2010, 10:94-100. | Article | PubMed

7. Klinge CM: Estrogen receptor interaction with estrogen response elements. Nucleic Acids Res 2001, 29:2905-2919. I Article | PubMed Abstract | PubMed Full Text

8. Honda K, Kajitani K, Nobeyama H, Kira Y, Yabunaka Y, Egami M, Zhi X, Fukuda T, Yoshida H, Matsumoto $Y$, Ichimura T, Yaui T, Sumi T, Ishiko $\mathrm{O}$ : An upstream estrogen response element linked to exogenous p53 tumor suppressor gene expression differentiates effects of the codon 72 polymorphism. Asian Pac J Cancer Prev 2011, 12:865-868. | Article I PubMed

9. Hackett NR, El Sawy T, Lee LY, Silva I, O'Leary J, Rosengart TK, Crystal RG: Use of quantitative TaqMan real-time PCR to track the time-dependent distribution of gene transfer vectors in vivo. Mol Ther 2000, 2:649-656. | Article | PubMed

10. Ishiwata I, Ishiwata C, Soma M, Arai J, Ishikawa H: Establishment of human endometrial adenocarcinoma cell line containing estradiol-17 beta and progesterone receptors. Gynecol Oncol 1984, 17:281-290. | Article I PubMed

11. Drewinko B, Yang LY, Leibovitz A, Barlogie B, Lutz D, Jansson B, Stragand JJ, Trujillo JM: Cellular discriminants for a biological classification of human colon carcinoma. Cancer Res 1984, 44:4241-4253. | Article | PubMed

12. Yaginuma $\mathrm{Y}$, Westphal $\mathrm{H}$ : Analysis of the $\mathrm{p} 53$ gene in human uterine carcinoma cell lines. Cancer Res 1991, 51:6506-6509. | Article | PubMed

13. Zhi X, Honda K, Sumi T, Yasui T, Nobeyama H, Yoshida H, Ishiko O: Es- tradiol-17beta regulates vascular endothelial growth factor and Bcl-2 expression in HHUA cells. Int J Oncol 2007, 31:1333-1338. | Article | PubMed

14. Menendez D, Inga A, Resnick MA: Estrogen receptor acting in cis enhances WT and mutant p53 transactivation at canonical and noncanonical p53 target sequences. Proc Natl Acad Sci U S A 2010, 107:1500-1505. | Article | PubMed Abstract | PubMed Full Text

15. Hernandez-Alcoceba R, Pihalja M, Wicha MS, Clarke MF: A novel, conditionally replicative adenovirus for the treatment of breast cancer that allows controlled replication of E1a-deleted adenoviral vectors. Hum Gene Ther 2000, 11:2009-2024. | Article I PubMed

16. Suomalainen M, Nakano MY, Boucke K, Keller S, Greber UF: Adenovirus-activated PKA and p38/MAPK pathways boost microtubule-mediated nuclear targeting of virus. EMBO J 2001, 20:1310-1319. | Article | PubMed Abstract | PubMed Full Text

17. Coleman KM, Dutertre M, El-Gharbawy A, Rowan BG, Weigel NL, Smith $\mathrm{CL}$ : Mechanistic differences in the activation of estrogen receptoralpha (ER alpha)- and ER beta-dependent gene expression by CAMP signaling pathway(s). J Biol Chem 2003, 278:12834-12845. I Article | PubMed

18. Dumont P, Leu JI, Della Pietra AC, 3rd, George DL, Murphy M: The codon 72 polymorphic variants of $\mathrm{p} 53$ have markedly different apoptotic potential. Nat Genet 2003, 33:357-365. I Article I PubMed

19. Palacios G, Crawford HC, Vaseva A, Moll UM: Mitochondrially targeted wild-type p53 induces apoptosis in a solid human tumor xenograft model. Cell Cycle 2008, 7:2584-2590. I Article I PubMed

20. Mori E, Takahashi A, Yamakawa N, Kirita T, Ohnishi T: High LET heavy ion radiation induces p53-independent apoptosis. J Radiat Res 2009, 50:37-42. | Article | PubMed

21. Yu J, Yue W, Wu B, Zhang L: PUMA sensitizes lung cancer cells to chemotherapeutic agents and irradiation. Clin Cancer Res 2006, 12:29282936. | Article | PubMed

22. Spitz FR, Nguyen D, Skibber JM, Meyn RE, Cristiano RJ, Roth JA: Adenoviral-mediated wild-type p53 gene expression sensitizes colorectal cancer cells to ionizing radiation. Clin Cancer Res 1996, 2:1665-1671. | Article | PubMed

23. Smith CL, Onate SA, Tsai MJ, O'Malley BW: CREB binding protein acts synergistically with steroid receptor coactivator-1 to enhance steroid receptor-dependent transcription. Proc Natl Acad Sci U S A 1996, 93:8884-8888. | Article | PubMed Abstract | PubMed Full Text

24. Shan B, Xu J, Zhuo Y, Morris CA, Morris GF: Induction of p53-dependent activation of the human proliferating cell nuclear antigen gene in chromatin by ionizing radiation. J Biol Chem 2003, 278:4400944017. | Article I PubMed

25. Grossman SR, Deato ME, Brignone C, Chan HM, Kung AL, Tagami $H$, Nakatani Y, Livingston DM: Polyubiquitination of $p 53$ by a ubiquitin ligase activity of p300. Science 2003, 300:342-344. | Article | PubMed

26. Karamouzis MV, Konstantinopoulos PA, Papavassiliou AG: Roles of CREB-binding protein (CBP)/p300 in respiratory epithelium tumorigenesis. Cell Res 2007, 17:324-332. | Article | PubMed

\section{Citation:}

Kajitani K, Honda KI, Terada H, Ayata M, Fukuda T, Yoshida H, Yasui T, Sumi T and Ishiko O: Estrogen response element enhances adenovirus-mediated transfer of the $\mathbf{p} 53$ gene according to codon 72 polymorphisms and cellular estrogen receptor expression. journal of Cancer Therapeutics and Research 2012, 1:31.

http://dx.doi.org/10.7243/2049-7962-1-31 